very thin and often only occur as scattered erratics. Thick deposits are restricted to the valley floors and to the outer parts of the coast. The principal deposits are of glacial, fluvio-glacial and colluvial facies, and less commonly, of marine or lacustrine facies. Stratigraphically the deposits are all late Quaternary. During their deposition the principal events in the area have been the intermittent retreat of the ice and the isostatic recovery of the area.

The glacial and fluvio-glacial deposits have been grouped into five morpho-lithostratigraphic units which show the successive stages in the recession of the Inland Ice and local glaciers. The history of this deglaciation is apparently as long as the deglaciation of what are now temperate regions.

The outer coast was deglaciated before 10000 BP $\left(C^{14}\right.$ dates by H. Tauber, National Museum, Copenhagen).

The close association of isostatic recovery with deglaciation means that the highest sea level, about $55 \mathrm{~m}$ above present sea level in this area, is of similar age as the deglaciation of the outer coast. Isostatic recovery was largely finished by $4000 \mathrm{BP}$.

Work is in progress relating the vegetational and edaphic history of the area to the deglaciation and isostatic recovery.

\title{
REMANENT MAGNETIC DIRECTIONS OF \\ SOME DYKES FROM SOUTHERN WEST GREENLAND
}

D. H. Tarling

During the summer of 1965 Survey geologists collected 57 oriented samples from 25 dykes for palaeomagnetic investigations. The main problem was to see if palaeomagnetic methods could be used to distinguish dyke swarms of different ages. Of the 25 dykes, two were thought to be "Trap Diabase" (TD) dykes of late Phanerozoic age and seven dykes were thought to be Gardar in age (ca. $1100 \mathrm{~m} . \mathrm{y}$.$) ; the other dykes were all of uncertain age.$

An estimate of the stability of remanence was made on ten pilot specimens chosen at random from the dykes which had been most extensively sampled. 
Afier the removal of specimens that are unstable, samples from four Gardar dykes and two TD dykes remained for further study. The mean remanent direction of the Gardar dykes is very shallow and westerly although the scatter between site directions is large. The two TD dykes have a mean direction which is northerly, steep and positively inclined. This direction is similar to the mean direction obtained by A.C.R. Ketelaar on the TD swarm in the Ivigtut area in 1963 (GGU internal report).

It is clear that there is a difference of about $90^{\circ}$ in the remanent magnetic directions of the Gradar and TD dyke swarms. The difference in direction of remanence is therefore optimum for distinguishing between the dyke swarms and most of the remaining dykes could be classified as probable Gardar or probable TD on the stable remanent directions.

\title{
CARBONATITE-LAMPROPHYRE DYKES OF MESOZOIC AGE
}

\author{
Brian Walton
}

Associated with the TD dolerites on Igaussaq island and the adjacent mainland south of Frederikshåb there occurs a parallel (NW-SE) swarm of carbonatite-lamprophyre dykes. These range in thickness from veins of a few millimetres to dykes of $1.5 \mathrm{~m}$. The carbonatites are most abundant in the extreme west of the area, as are the TD dolerites, and die out towards the east. They cut all generations of dykes earlier than TD, and in one case can be seen to be intruded into a TD parallel to its margin. This field evidence suggests that they are probably contemporaneous with the TD dolerites. An isotopic age date for one of these carbonatites is given in the article by Ole Larsen at the end of this volume.

The carbonatites are perfectly fresh rocks consisting of a fine-grained carbonate matrix containing abundant euhedral to ovoid zoned phenocrysts of pyroxene, amphibole and biotite. In thin section the cores of the pyroxenes are pale green, the margins very pale pink, whilst the amphiboles have green cores and brown margins. Some dykes contain considerable olivine which is largely pseudomorphed by carbonate. The dominant accessory is magnetite. 